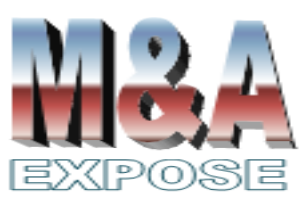

http://jurnal.usahid.ac.id/index .php/accounting
${ }^{1,2}$ Fakultas Ekonomi Universitas Pembangunan Nasional "VETERAN" Jakarta kirana gintina@yahoo.com

\section{Peranan Corporate Governance terhadap Kinerja Perusahaan Family Ownership di Indonesia}

\author{
Dwi Jaya Kirana ${ }^{1}$, Ernawati ${ }^{2}$
}

\section{Abstrak}

Tujuan penelitian ini untuk mengetahui peran good corporate governance pada perusahaan family ownership serta pengaruh good corporate governance terhadap kinerja perusahaan dan nilai perusahaan pada perusahaan publik yang terdaftar di Bursa Efek Indonesia. Metode pengambilan sampel yang digunakan adalah purposive sampling atas seluruh perusahaan publik yang terdaftar di Bursa Efek Indonesia, kecuali perusahaan keuangan dan Badan Usaha Milik Negara. Teknik dan metode analisis data yang digunakan dalam penelitian ini adalah metode regresi linier berganda. Hasil penelitian menyimpulkan Indeks Corporate Governance berpengaruh signifikan positif terhadap kinerja perusahaan baik terhadap Return On Assets maupun Price Book Value; kepemilikan keluarga berpengaruh negatif terhadap kinerja Return On Assets; dan interaksi corporate governance dengan family ownership tidak berpengaruh terhadap kinerja perusahaan.

Kata kunci : good corporate governance; kepemilikan keluarga; kinerja perusahaan.

\section{Abstract}

The purpose of this study is to find out whether good corporate governance can bridge the family ownership company in Indonesia in the problem and whether it can improve the company's performance as well as the value of the company in the company listed in the Indonesia Stock Exchange. So as to know how big the role of corporate governance in corporate family ownership in Indonesia and its impact on company performance. In this research the sampling method used is purposive sampling on public companies listed in Indonesia Stock Exchange. Technique and method of data analysis used in this research is doubled linear regression method. The results of this study are Corporate Governance Indeks shows a significant positive effect on the company's performance both on the ROA and PBV and family ownership shows a significant negative effect just on ROA's performance. And corporate governance interaction with family ownership does not affect the company's performance.

Keywords : good corporate governance, family ownership, corporate performance. 


\section{PENDAHULUAN}

Para pelaku bisnis dari berbagai macam bisnis korporasi menjalankan sistem tata kelola perusahaannya secara terbuka, sistimatis dan bertanggung jawab. Hal ini didorong kebutuhan pasar yang menuntut perusahaan publik menjalankan sistem manajemennya secara baik, transparan dan auditable. Sistem tata kelola perusahaan yang tertib dan terbuka ini, biasa disebut Good Corporate Governance (GCG), dipromosikan lebih lanjut oleh berbagai kalangan akademis dan lembaga keuangan dunia seperti the World Bank dan Asian Development Bank. Dewasa ini sebagian besar buku wajib manajemen umum dan strategic management membahas implementasi GCG dan menyarankan agar GCG dijalankan oleh perusahaan-perusahaan modern di dunia.

Silveira dan Barros (2006) meneliti pengaruh kualitas corporate governance terhadap nilai pasar. Temuan mereka menunjukkan pengaruh kualitas corporate governance yang positif signifikan terhadap nilai pasar perusahaan. Klapper dan Love (2002) juga menemukan adanya hubungan positif antara corporate governance dengan kinerja perusahan yang diukur dengan Return On Asset (ROA) dan Tobin's Q.

Dalam perkembangan perekonomian saat ini, perusahaan keluarga telah diakui sebagai salah satu struktur tata kelola organisasi bisnis baik dalam negara maju maupun negara berkembang. Di Indonesia pada akhir 2014, untuk pertama kalinya Price WaterHouse Cooper (PwC) survei mengenai bisnis keluarga di Indonesia yang menyimpulkan lebih dari 95 persen perusahaan di Indonesia merupakan bisnis keluarga. PwC mendefinisikan bisnis keluarga sebagai perusahaan yang mayoritas hak suaranya berada di tangan pendiri atau orang yang mengakuisisi perusahaan, misalnya pasangan, orang tua, anak atau ahli waris. Setidaknya ada satu perwakilan keluarga yang terlibat di dalam manajemen atau administrasi perusahaan, sedangkan untuk perusahaan publik keluarga biasanya menguasai $25 \%$ saham perusahaan dan setidaknya terdapat satu orang anggota keluarga menduduki jabatan perusahaan. (CNN Indonesia, 2014).

Perusahaan di Indonesia yang rata-rata kepemilikannya dimiliki keluarga rentan mengalami konflik karena perbedaan kepentingan antara manajemen dengan pemegang saham. Kepemilikan mayoritas yang dimiliki keluarga akan lebih beresiko konflik dikarenakan adanya peran keluarga yang sangat dominan untuk memonitor dan mengelola jalannya perusahaan. Semakin besar porsi kepemilikan keluarga dalam perusahaan maka akan semakin besar resiko yang ditanggung jika perusahaan tidak berjalan sesuai yang diharapkan.

Permasalahan yang sering timbul dari perusahaan family ownership dengan pemegang saham minoritas, yaitu timbul kecurigaan terhadap pemegang saham mayoritas yang diduga akan merugikan pemegang saham minoritas. Permasalahan timbul karena biasanya terjadi kompensasi yang berlebihan kepada manajer selaku pengelola perusahaan yang merupakan anggota keluarga pemilik perusahaan dan cenderung mengambil manfaat pribadi dari perusahaan dengan semakin banyak nilai saham yang diinvestasikan maka semakin mudah untuk mengendalikan perusahaan. Ketika timbul suatu resiko yang sangat tinggi yang dialami oleh perusahaan, maka pemilik cenderung lebih menyelamatkan uang yang mereka investasikan daripada memperbaiki kinerja perusahaan.

Anderson dan Reeb (2004) yang melakukan penelitian di Indonesia menemukan bahwa kepemilikan keluarga berpengaruh negatif terhadap kinerja keuangan perusahaan. Fenomena ini disebabkan karena perlindungan hukum terhadap investor dalam struktur 
kepemilikan sangat lemah sehingga timbul masalah agensi yang dapat mengganggu kinerja perusahaan. Jiang dan Peng (2011) meneliti 744 perusahaan yang listed di delapan negara Asia termasuk Indonesia dan menemukan perusahaan keluarga memiliki pengaruh pada kinerja perusahaan secara berbeda di setiap negara pemegang saham minoritas yang diproteksi oleh hukum dan regulasi institusi negara masing-masing.

Corporate governance merupakan sistem yang dibuat dan wajib dilakukan oleh setiap perusahaan yang go public untuk mengendalikan perusahaan supaya tercapai keseimbangan antara manajemen dengan stakeholder. Kegunaan corporate governance merupakan cara yang bisa mengurangi masalah keagenan yang timbul. Tujuan penelitian ini adalah untuk menganalisis sejauh mana good corporate governance dapat menjembatani perusahaan family ownership di Indonesia dalam permasalahan manajemennya, serta bagaimana kontribusinya dalam meningkatkan kinerja perusahaan terbuka yang terdaftar di Bursa Efek Indonesia.

\section{TINJAUAN PUSTAKA}

Corporate Governance. Isu tentang corporate governance telah popular di akhir tahun 2000 yaitu sesudah terjadinya krisis ekonomi di tahun 1997. Penelitian yang dilakukan oleh Asian Development Bank (ADB, 2000) menyatakan bahwa corporate governance yang lemah merupakan salah satu faktor penting terjadinya krisis, sehingga isu corporate governance menjadi agenda perusahaan dan kebijakan ekonomi, terutama sektor perbankan.

Di Indonesia keinginan untuk menerapkan prinsip-prinsip GCG dilakukan oleh berbagai pihak baik secara paksa maupun voluntary. Pemerintah, misalnya melalui Kantor Menteri BUMN telah mengeluarkan pedoman untuk perusahaan-perusahaan BUMN dalam menjalankan GCG di perusahaan masing-masing. Demikian juga Bursa Efek Indonesia, mewajibkan pada perusahaan emiten untuk membentuk berbagai komite pengawasan yang sejalan dengan tertib pengelolaan perusahaan yang transparan dan bertanggung jawab. Pada beberapa perusahaan swasta, aplikasi GCG telah dilakukan secara alamiah, karena mereka merasakan manfaat penerapan GCG tersebut.

Dua mekanisme internal corporate governance yang penting adalah board governance dan ownership structure. Good corporate governance tidak akan terlaksana dengan baik tanpa adanya peranan dewan, baik dewan komisaris maupun dewan direksi. Jika perusahaan memiliki board governance yang baik maka diyakini akan memiliki kinerja perusahaan yang baik juga. Komposisi dewan, baik dewan komisaris ataupun dewan direksi, akan berdampak terhadap kualitas keputusan dan kebijakan yang dibuat dalam mengefektifkan pencapaian tujuan perusahaan.

Pentingnya corporate governance juga ditekankan oleh berbagai kalangan akademisi dengan tujuan akhir bahwa aplikasi konsep ini di perusahaan dapat memberikan nilai tambah perusahaan secara berkelanjutan (sustainable) dan sekaligus memberikan manfaat bagi kepentingan para pemegang saham dan stakeholdersyang terkait.

Durnev dan Kim (2005), dengan sampel 494 perusahaan dari 24 negara termasuk Indonesia, meneliti atribut perusahaan yang mempengaruhi pemilihan praktik corporate governance. Mereka juga meneliti pengaruh praktik corporate governance terhadap nilai perusahaan. Penelitian mereka menunjukkan bahwa pemilihan praktik CG dan praktik 
tingkat pengungkapan berhubungan positif dengan kesempatan pertumbuhan perusahaan. Hubungan mereka diperkuat pada negara yang perlindungan hak investornya lemah. Ketika negara tidak melindungi hak investornya dengan baik, perlu pendanaan eksternal bagi perusahaan yang akan berpengaruh besar pada pemilihan praktik corporate governance perusahaan.

Cheung, et al. (2018) menilai kualitas corporate governance di perusahaan yang listing di China. Berdasarkan OECD 2014, mereka mengembangkan corporate governance index (CGI) untuk mengukur kualitas tata kelola dan pengungkapan pada 100 perusahaan terbesar yang listing di China. Hasilnya menunjukkan adanya progress dalam reformasi tata kelolanya. Terlihat adanya perbedaan signifikansi dalam CGI dari perusahaan kinerjanya di atas dengan di bawah. Perusahaan oversea yang listing di China lebih menghargai pengungkapan dan transparansi dibandingkan yang non overseas yang listing di China. Hasil pengujian juga menunjukkan tidak signifikannya hubungan kualitas tata kelola perusahaan dengan penilaian pasar. Walaupun hasil penelitian sebelumnya mengenai hubungan corporate governance dan kinerja perusahaan masih beragam, namun dalam penelitian ini akan dilakukan pengujian kembali atas hal tersebut.

Penelitian Silviera dan Barros (2007) menguji pengaruh kualitas corporate governance dengan indeks corporate governance terhadap nilai pasar dari 154 perusahaan yang listing di Brazil pada tahun 2002. Hasilnya menunjukkan kualitas CG positif signifikan mempengaruhi nilai pasar.

Berdasarkan kajian teori dan temuan penelitian sebelumnya tersebut, maka dirumuskan hipotesis 1 : Corporate Governance berpengaruh positif terhadap kinerja perusahaan.

Family Ownership. Dalam perkembangan perekonomian saat ini, perusahaan keluarga telah diakui sebagai struktur tata kelola dari organisasi bisnis baik di negara maju maupun berkembang. Menurut Siregar dan Utama (2008), family ownership adalah kepemilikan yang bukan merupakan kepemilikan pemerintah maupun institusi keuangan.

Salah satu keunggulan perusahaan keluarga adalah orientasi jangka panjang terhadap bisnis karena asumsi kelangsungan bisnis terkait langsung dengan kelangsungan hidup keluarga. Jika perusahaan bangkrut, keluarga tidak lagi eksis. Di samping itu, perusahaan dan produk sangat mempengaruhi identitas anggota keluarga sehingga jika produk dipersepsikan cacat atau bermutu rendah, seakan-akan merefleksikan diri mereka. Jadi sebuah perusahaan keluarga kemungkinan tidak tertarik untuk memperoleh keuntungan financial jangka pendek yang dapat menodai kedudukan perusahaan.

Andres (2007) meneliti 275 perusahaan listed di Jerman 1998-2004 dan menunjukkan bahwa perusahaan keluarga lebih menguntungkan dibandingkan dengan perusahaan yang struktur pemegang sahamnya tersebar. la menyimpulkan perusahaan keluarga sebagai struktur kepemilikan yang ideal untuk mengurangi masalah dua agensi. Permasalahan keagenan yang pertama yaitu masalah agensi dengan manajer perusahaan dikarenakan kendali perusahaan keluarga lebih banyak akibat ada salah satu keluarga yang bekerja sebagai manajer perusahaan keluarga, sedangkan permasalahan keagenan yang kedua adalah ekspropriasi pemegang saham minoritas yang sering dikeluhkan.

Benhart dan Rosenstein (2008) membuktikan bahwa semakin tinggi perwakilan dari outside director maka semakin tinggi independensi dan efektifitas corporate board sehingga meningkatkan nilai perusahaan. Anderson dan Reeb (2003) memberikan perspektif baru peranan dari independent director dalam corporate governance yaitu mengurangi konflik 
antar pemegang saham, lebih spesifik apakah independent director bisa mengurangi konflik agensi antar kepemilikan keluarga dengan pemegang saham dari luar. Dan hasilnya konsisten bisa mengurangi konflik antar kepemilikan keluarga dan shareholder luar. Dengan berkurangnya konflik antar kepemilikan keluarga dan shareholder luar, maka menunjukkan hubungan positif antara board independence dengan kinerja perusahaan pada perusahaan yang dimiliki keluarga. Mereka juga menguji pada perusahaan non kepemilikan keluarga, hasilnya menunjukkan tidak signifikannya pengaruh antara board independence dengan kinerja perusahaan.

Siregar dan Utama (2008) menemukan bahwa kepemilikan keluarga berpengaruh signifikan terhadap tipe pengelolaan laba dan perusahaan yang memiliki proporsi yang tinggi dalam kepemilikan keluarga dan grup non bisnis lebih efisien manajemen labanya dibandingkan tipe perusahaan lainnya. Jika perusahaan melakukan manajemen laba yang efisien, maka dapat menaikkan kinerja perusahaan tersebut.

Jiang dan Peng (2011) meneliti 744 perusahaan yang listed di delapan negara Asia (Hongkong, Indonesia, Malaysia, Philiphina, Singapura, Korea Selatan, Taiwan dan Thailand) dan menemukan perusahaan keluarga berpengaruh pada kinerja perusahaan yang secara berbeda-beda di setiap negara. Temuannya secara sistematik dihubungkan dengan pemegang saham minoritas yang diproteksi oleh hukum dan regulasi institusi negara masing-masing.

Wiranata dan Nugrahanti (2013) menguji 224 perusahaan manufaktur di Indonesia, dengan kesimpulan bahwa kepemilikan asing dan leverage berpengaruh positif terhadap profitabilitas perusahaan, sedangkan kepemilikan keluarga memiliki pengaruh negatif terhadap profitabilitas perusahaan.

Beberapa penelitian tersebut menunjukkan hasil yang tidak konsisten terkait pengaruh dari kepemilikan keluarga terhadap kinerja maupun nilai perusahaan dikarenakan regulasi dan hukum yang berbeda-beda di setiap negara.

Berdasarkan kajian teori dan temuan penelitian sebelumnya tersebut, maka dirumuskan hipotesis 2 : kepemilikan saham keluarga berpengaruh negatif terhadap kinerja perusahaan. Adapun hipotesis 3 : Corporate Governance berpengaruh mengurangi pengaruh Family Ownership terhadap kinerja dan nilai perusahaan.

\section{METODE PENELITIAN}

Penelitian ini menggunakan data sekunder dari laporan tahunan 139 perusahaan yang listing di Bursa Efek Indonesia. Metode pemilihan sampel dengan metode purposive sampling dengan kriteria tertentu semua perusahaan yang listing di Bursa Efek Indonesia kecuali perusahaan di bidang jasa keuangan dan BUMN.

Persamaan matematis model penelitian adalah sebagai berikut :

ROAit $=\alpha 0+\alpha 1 I C G_{i t}+\alpha 2 F A M_{i t}+\alpha 3 F A M^{*} I C G_{i t}+\varepsilon_{i t}$

PBVit $=\alpha 0+\alpha 1 I C G_{i t}+\alpha 2 F A M_{i t}+\alpha 3 F A M^{*} I C G_{i t}+\varepsilon_{i t}$

Keterangan :

$\mathrm{ICG}=$ Indeks Corporate Governance

$\mathrm{ROA}=$ Return On Assets

$\mathrm{PBV}=$ Price Book Value

FAM = persentase kepemilikan keluarga 
Teknis analisis menggunakan regresi linier berganda. Variabel dependen meliputi Price Book Value (PBV) dan Return On Assets (ROA). Sedangkan variabel independen adaalh kepemilikan keluarga/family (FAM) yang merupakan persentase saham yang dimiliki oleh keluarga dan Indeks Corporate Governance (ICG) yaitu Indeks Corporate Governance dari Cheung Y.L., dkk. (2008). Siregar \& Utama (2008) menyatakan bahwa kepemilikan keluarga adalah semua perusahaan yang listed di atas 5 persen tidak termasuk pemerintah, institusi keuangan, atau publik. Data persentase kepemilikan saham keluarga pada perusahaan di Indonesia diperoleh dari Laporan Keuangan Auditan, pada bagian catatan atas laporan keuangan.

\section{HASIL DAN PEMBAHASAN}

Analisis penelitian ini diawali dengan analisis statistik deskriptif yang disajikan di Tabel 1, sampel awal pengujian hipotesis adalah 148 perusahaan, tetapi terdapat 9 data outlier. Outlier adalah observasi yang nilai datanya memiliki simpangan yang cukup jauh dari rata-rata, yaitu jika Zscore-nya di atas 3 atau di bawah -3 (Hair et al., 2006), sehingga jumlah sampel menjadi 139 perusahaan. Terlihat dalam tabel tersebut nilai minimum dan maksimum dalam dependen ROA adalah $-13,61$ dan 23,57 dan terlihat juga dalam dependen PBV nilai ekstrimnya -1,90 dan 5,38 dan terlihat dari standar deviasinya 1,27 lebih kecil dibandingkan ROA yaitu 6,63.

Tabel 1. Statistik deskriptif

\begin{tabular}{lrrrrr}
\hline & $N$ & \multicolumn{1}{c}{ Minimum } & \multicolumn{1}{c}{ Maximum } & \multicolumn{1}{c}{ Mean } & \multicolumn{1}{c}{ Std. Deviation } \\
\hline ROA & 139 & $-13,61$ & 23,57 & 5,1642 & 6,63655 \\
PBV & 139 & $-1,90$ & 5,38 & 1,5573 & 1,27098 \\
IG & 139 & 48,75 & 89,42 & 67,6656 & 9,86337 \\
FAM & 139 & 5,00 & 99,84 & 50,6429 & 28,39223 \\
\hline
\end{tabular}

Sumber :data diolah (tahun 2017)

Struktur kepemilikan keluarga dalam sampel paling tinggi 99,84 persen dari nilai minimal 5 persen, dan rata-rata kepemilikan keluarga dalam sampel penelitian sebesar 50,64 persen. Ini menunjukkan perusahaan yang terdaftar di Indonesia mayoritas perusahaan didominasi struktur kepemilikan keluarga. Standar deviasi FAM relatif tinggi sebesar 28,39 persen menggambarkan adanya variasi kepemilikan keluarga yang cukup besar. Variasi tingkat kepemilikan keluarga tersebut merupakan indikasi awal bahwa kepemilikan keluarga merupakan variabel penting yang harus dipertimbangkan dalam menjelaskan hubungan variabel lain dalam model penelitian ini.

Dari hasil uji statistik rata-rata indeks corporate governance berada di kisaran 60 persen, bagi regulator merupakan informasi penting untuk mengevaluasi kebijakan pemerintah dalam meningkatkan kualitas corporate governance dilihat dari struktur board perusahaan, sehingga kualitas corporate governance meningkat tidak hanya di kisaran 60 persen. Ini menunjukkan kemungkinan praktik CG perusahaan di Indonesia hanya sebatas pemenuhan ketentuan pemerintah namum belum diterapkan dengan efektif.Investor khususnya bagi pemegang saham, diharapkan memperhatikan corporate governance perusahaannya sebagai bahan pertimbangan berinvestasi untuk menghindari kemungkinan 
kerugian investasi karena dengan kualitas corporate governance yang baik akan berpengaruh dengan kinerja perusahaan yang baik juga sesuai hasil penelitian ini, sebagai bahan pertimbangan untuk berinvestasi. Sedangkan bagi perusahaan, walau masih banyak belum mempunyai nilai skor yang cukup bagus, hanya sebatas rata-rata, dengan mengetahui menerapkan CG dengan baik akan berdampak pada kinerja perusahaan itu sendiri dengan signifikan, jadi jika perusahaan ingin meningkatkan kinerjanya sebaiknya perusahaan meningkatkan praktik corporate governance-nya.

Tabel 2. Hasil Analisis Regresi Linier Berganda

\begin{tabular}{lrrrrrr}
\hline \multicolumn{1}{c}{ Variabel } & Koefisien & $\mathrm{t}$ & Signifikan & Koefisien & $\mathrm{t}$ & \multicolumn{1}{c}{ Signifikan } \\
\hline Konstanta & $-20,887$ & $-2,609$ &, 010 & $-5,584$ & $-3,789$ &, 000 \\
IG &, 121 & 2,150 &, $033^{* *}$ &, 041 & 3,859 &, $000^{* * *}$ \\
FAM &,- 046 & $-2,555$ &, $012^{* *}$ &, 002 &, 502 &, 616 \\
IG*FAM &,- 003 &,- 743 &, 459 &, 000 &, 439 &, 661 \\
N & 139 & & & 139 & \\
Adjusted R2 & & 0,207 & & & 0,210 & \\
F- Statistik & & & & 8,335 & \\
Prob F & & & & & $0,000^{* * *}$ & \\
\hline
\end{tabular}

*** signifikan pada $1 \%,{ }^{* *}$ signifikan pada $5 \%$, signifikanpada $10 \%$

Sumber :data diolah (tahun 2017)

Pada uji t terlihat IG berpengaruh positif terhadap ROA, dan nilai $t-2,555$ pada variabel FAM berarti variabel tersebut secara individual berpengaruh negatif signifikan terhadap ROA. Variabel IG mempunyai signifikansi 5 persen, ini menunjukkan IG berpengaruh positif secara signifikan terhadap ROA sesuai dengan hipotesis 1. Kualitas indeks dilihat keseluruhan dari kualitas board perusahaan berpengaruh positif terhadap kinerja ROA. Kualitas pengelolaan perusahaan yang baik akan berdampak pada peningkatan ROA perusahaan.

Kepemilikan keluarga berpengaruh negatif terhadap kinerja perusahaan, sesuai hasil penelitian Peng dan Jiang (2006). Kepentingan pribadi dari anggota keluarga lain mungkin membahayakan kinerja perusahan karena kompetisi antar anggota keluarga lain yang berkeinginan meningkatkan kekuasaan dan prestige dibandingkan meningkatkan laba dan kurangnya profesionalisme dalam pengelolaan perusahaan keluarga.

Hasil uji $\mathrm{t}$ menunjukkan IG berpengaruh signifikan positif di tingkat 1 persen terhadap variabel PBV berarti hipotesis 1 diterima. Ini menunjukkan pasar merespon positif dengan kualitas pengelolaan secara keseluruhan dari kualitas board of governance perusahaan. Sesuai pernyataan Tony Roland Silitonga, Direktur Eksekutif Indonesian Institute for Corporate Directorship mengungkapkan penelitian McKinsey terakhir menunjukkan investor breast minimum US\$300 miliar menyatakan lebih percaya pada perusahaan berdasarkan indeks GCG-nya ketimbang financial statement (SWA, 2008).

Sedangkan variabel Kepemilikan keluarga (FAM) dilihat dari kinerja pasar PBV tidak berpengaruh signifikan, berarti hipotesis ditolak. Ini menunjukkan di Indonesia perusahaan yang struktur kepemilikan dimiliki keluarga tidak berpengaruh terhadap kinerja pasar. Sesuai dengan La Porta et al. (1999), ada kemungkinan pemegang saham mayoritas akan mengekspropriasi pemegang saham minoritas sehingga pasar kurang berminat pada saham-saham yang dimiliki keluarga. 
Interaksi corporate governance dengan family ownership menunjukkan tidak berpengaruh terhadap kinerja perusahaan ROA dan PBV, berarti corporate governance belum mengurangi masalah yang mungkin timbul dari kepemilikan keluarga untuk mendapatkan kinerja lebih baik.

\section{KESIMPULAN}

Berdasarkan hasil analisis dan pengujian dalam penelitian, maka diperoleh kesimpulan bahwa Corporate Governance berpengaruh positif secara signifikan terhadap kinerja ROA dan PBV, sedangkan kepemilikan keluarga berpengaruh negatif secara signifikan terhadap kinerja perusahaan ROA tapi PBV tidak berpengaruh, dan interaksi corporate governance dengan family ownership tidak berpengaruh terhadap kinerja perusahaan. Penelitian ini memiliki keterbatasan hanya menggunakan sampel penelitian tahun 2014 dan 2015, sehingga hasil penelitian ini belum mengakomodasi kemungkinan hubungan antar variabel dalam jangka panjang. Hasil penelitian ini juga belum dapat digeneralisasi ke seluruh perusahaan yang terdaftar di BEI, karena kelompok industri jasa keuangan dan investasi tidak termasuk ke dalam sampel. Industri tersebut dikeluarkan karena termasuk highly regulated industry. Operasionalisasi variabel indeks CG juga memiliki keterbatasan karena adanya kemungkinan kurangnya merepresentasikan CG yang ada di Indonesia karena pengukuran indeks CG tersebut menggunakan data sekunder bukan berdasarkan hasil observasi dan wawancara langsung di perusahaan. Penelitian berikutnya diharapkan dapat mengembangkan instrumen pengukuran CG yang lebih representatif.

\section{DAFTAR PUSTAKA}

Anderson, R.C. dan Reeb, D.M. 2003. Founding-family ownership and firm performance evidence from the S\&P 500. Journal of Finance. Vol. 58, pp. 1301-1328.

Anderson, R.C. Mansi, S.A. dan Reeb, D.M. 2003. Founding family ownership and the agency cost of debt. Journal of Financial Economics. Vol. 68, pp. 263-285.

Bhagat, S. dan Black, B. 1999. The Uncertain Relationship Between Board Composition and Firm Performance. Diakses dari www.ssrn.com.

Boone, A. Field, L. Karpoff, J. dan Raheja, C.G. 2007. The Determinants of Corporate Board Size and Composition: An Empirical Analysis. Journal of Financial Economics. Vol. 85, pp. $66-101$.

Cheung Y.L. Ping Jiang. Piman Limpaphayom. dan Tong Lu. 2008. Does Corporate Governance Matter in China?. China Economic Review. Vol. XX, pp. 1-12.

Damodaran, A. 1996. Investment Valuation, Tools and Technic for Determining the Value of Any Asset. John Willey \& Sons. Inc. Singapore.

Durnev, A. dan Kim E.H. 2005. To Steal or Not to Steal : Firm Attributes, Legal Environment and Valuation. Journal of Finance. Vol. 60 No. 3, pp. $1461-1493$.

Ismiyanti, F. dan Mahadwartha, P.A. 2008. Does Debt Affect Firm Finansial Performance? The Role of Debt on Corporate Governance in Indonesia. Jurnal Riset Akuntansi Indonesia. Vol. 11 No. 1.

Jensen, M.C. dan Meckling, W.H. 1976. Theory of The Firm : Managerial Behavior, Agency Cost and Ownership Structure. Journal of Financial Economics. Vol.3, pp. $305-360$. 
Keputusan Direksi PT Bursa Efek Jakarta No. Kep-315/BEJ/06-2000 Tentang Kebijakan Board Governance.

Lefort, F. dan Urzua, F. 2007. Board Independence, Firm Performance and Ownership concentration: Evidence from Chile. Diakses dari www.ssrn.com.

Lukviarman, N. 2004. Ownership structure and Firm Performance: The Case of Indonesia. Disertasi. Graduate School of Business. Curtain University of technology. Perth.

NG, Christina, Y.M. 2005. An Empirical Study on The Relationship Between Ownership and Performance in A Family-Based Corporate Enviroment. Journal of Accounting, Auditing and Finance. Spring 2005. Vol. 20 Issue. 2, pp. 121 - 146.

Peng, M. dan Jiang, Y. 2006. Family Ownership and Control in Large Firms, The Good, the Bad, The Irrelevant - and Why. William Davidson Institute Working Paper. No. 840.

Ross, Westerfield. Jaffe. dan Jordan. 2008. Modern Financial Management, eight edition Mg.Graw Hill International edition 472 - 473.

Silva, F. dan Majlu, N. 2008. Does Family Ownership Shape Performance Outcomes. Journal of Business Research. Vol. 61, pp. $609-614$.

Silviera, A Di M. da, dan Barros, L.A. 2007. Corporate Governance Quality and Firm Value in Brazil. Diakses dari www.ssrn.com

Siregar, S.V. \& Utama S. 2008. Type of Earning Managemen and The Effect of Ownership Structure. The International Journal of Accounting.

Surat Edaran Menteri Negara/Kepala Badan Penanaman Modal dan Pembinaan Badan Usaha Milik Negara tanggal 17 April 2000 Tentang Kebijakan Penerapan Corporate Governance. S-106/M-PM.PBUMN/2000.

Swa Sembada (Mei -Juni 2008).

UU RI No. 40. 2007. Tentang Perseroan Terbatas.

Villalonga, B. and Amit, R. 2006. How Do Family Ownership, Management and Control Affect Firm Value?. Journal of Financial Economics. Vol. 80, pp. $385-417$.

Wild J.J. Subramanyam, K.R. dan Halsey. R.F. Financial Statement Analysis. 8 th edition Book 2. New York. McGraw Hill.

White, G. CFA. Sondhi, A.C. dan Fried, D. 2003. The Analysis and Uses of Financial Statement. John Wiley \& Sons. Inc.S 